\title{
'A Considerable Degree Removed from Pauperism'?: The Social Profile of Fee-Paying Patients
}

During the 1857-1858 commission, Nugent emphasised the permeability of class boundaries among asylum patients. When asked if he considered paying patients in district asylums to be 'generally of a class little above paupers', Nugent replied:

Very little above paupers. A man has sixty or eighty acres of ground; his beneficial interest in that will probably be $£ 120$ or $£ 130$ a-year, out of which he has to maintain himself, his wife and probably four or five children. That man cannot swear that he is a pauper and if he has a lunatic child, he offers at an asylum as much as he would expend on that child in his own house.

The commissioners pressed this point, querying whether this man would not be 'a considerable degree removed from pauperism' but Nugent clarified his statement, stressing that 'if he is obliged to pay $£ 40$ or $£ 50$ a-year for one lunatic child, he will be doing a gross injustice to his wife and other children and he will be pauperising himself and family'. ${ }^{1}$ Nugent was suggesting that patients' financial circumstances should not be measured in isolation, but rather in terms of their family unit and the number of dependents outside, as well as inside, the asylum. ${ }^{2}$

Social categories such as 'higher orders', 'lunatic poor' and 'the great class which lies between' are often misleading and should not be misread as signposts of social class. ${ }^{3}$ As Melling and Forsythe have found in their analysis of four Devon asylums, asylum populations should also be understood in relation to their occupational status, economic resources,

(C) The Author(s) 2018

A. Mauger, The Cost of Insanity in Nineteenth-Century

Ireland, Mental Health in Historical Perspective, https://doi.org/10.1007/978-3-319-65244-3_4 
the social and collective resources available, their market power and employment status. ${ }^{4}$ While examination of patients' former occupations therefore offers some indication of their socio-economic background, these data must be interpreted sensitively. This chapter's primary concern is to identify the various social groups committed to district, voluntary and private asylums. For these purposes, analysis of the socio-economic profile of paying patients, their land and business interests and their maintenance fees serves to highlight, rather than define, social diversity within asylum populations.

Based on her survey of the lunacy inspectors' reports, Walsh has argued that private asylum patients in Ireland were predominantly male and single. ${ }^{5}$ Malcolm has found that patients admitted to St Patrick's (voluntary asylum) during the 1870s and 1880s were typically members of the Church of Ireland, female and single. ${ }^{6}$ Building on these analyses, this chapter provides the first comparative study of paying patients admitted to nine Irish asylums: Belfast, Ennis, Enniscorthy and Richmond district asylums, Stewarts and Bloomfield voluntary asylums and St John of God's, Hampstead and Highfield private asylums. Drawing heavily on statistics gleaned from asylum records (for methodology, see Appendix A), it charts admissions in two phases: the first to Bloomfield and Hampstead between 1826 and 1867, and the second to the nine asylums studied between 1868 and 1900. In doing so, it explores patients' gender, marital status, religious denomination and former occupation.

\section{Gender And Family Ties}

Historians of psychiatry have long placed value on surveys of asylum patients' gender. In her study of residence rates, medical texts and literature, Elaine Showalter has suggested that doctors in Victorian England considered women to be particularly prone to insanity, giving rise to its depiction as a 'female malady'. 7 Busfield has disputed this finding, attributing women's numerical predominance in English asylums to mounting numbers of female patients who tended to stay longer. ${ }^{8}$ These findings also apply to private asylums. ${ }^{9}$ Commenting on Ticehurst patients, MacKenzie has suggested that 'families who were dependent on a male breadwinner for a high income may have felt it worth staking a considerable proportion of their financial resources on the chance of a cure' ${ }^{10}$ Similarly, Walsh has posited that the higher proportion of men in Irish private asylums might reflect families' greater willingness to pay for male relatives' treatment due to their 'greater economic importance'. ${ }^{11}$ 
From 1826 to 1867 , the Hampstead private asylum admitted more men $(65 \%)$ than women, while the Bloomfield voluntary asylum received more women $(61.1 \%)$ than men. These trends changed little over the century, despite the continued expansion of asylum care and sanctioning of paying patients in district asylums. Between 1868 and 1900, approximately $60 \%$ of paying patients admitted to the district asylums studied were male (see Table 4.1) with little regional variation. This is especially striking given that there were more women in Ireland in this period. ${ }^{12}$ It conforms broadly to surveys of total district asylum populations (pauper and paying patients), which have identified a predominance of male admissions. ${ }^{13}$ St John of God's asylum limited admissions to men only and, taken together, sister asylums Highfield, which admitted women only, and Hampstead, which admitted men only after Highfield was established, had a wide disparity between the sexes: $66.8 \%$ of first admissions were men. These findings support those of MacKenzie and Walsh in suggesting that families were more willing to procure expensive private asylum care for their male relatives. ${ }^{14}$

Although Walsh has suggested that there were fewer women in private asylums because they were easier to care for at home, ${ }^{15}$ there is scant evidence to support this contention. The two voluntary asylums, Stewarts and Bloomfield, admitted more women than men. Moreover, the very existence of St Vincent's voluntary asylum, which catered exclusively for women, signifies the willingness of families to purchase asylum care for women. In her study of the York Retreat, Anne Digby contends that while families considered expensive medical treatment as a 'form of investment particularly suited for the male bread-winner, the subsidised treatment available at the Retreat was an inducement for women to be

Table 4.1 Gender of first admissions to the case studies, 1868-1900

\begin{tabular}{lllll}
\hline Asylum & Male & $(\%)$ & Female & $(\%)$ \\
\hline Paying patients in district asylums & 418 & 60.1 & 278 & 39.9 \\
Stewarts & 177 & 40.1 & 264 & 59.9 \\
Bloomfield & 90 & 35.6 & 163 & 64.4 \\
St John of God's & 405 & 100.0 & 0 & 0.0 \\
Hampstead and Highfield & 219 & 66.8 & 109 & 33.2 \\
Total & 1309 & 100.0 & 814 & 100.0 \\
\hline
\end{tabular}

Compiled from Belfast, Ennis, Enniscorthy, Richmond, Stewarts, Bloomfield, St John of God's and Hampstead admissions registers, 1868-1900

a The first admission to St John of God's was in 1885 
sent there'. ${ }^{16}$ Digby's argument goes some way towards accounting for the larger number of women admitted to Bloomfield and Stewarts.

Yet it would be mistaken to argue that families were simply unwilling to invest larger amounts in the care of their female relatives. As Table 4.2 indicates, male district asylum patients were only marginally more likely to be maintained at high rates (over £20). Stewarts and Bloomfield tended to charge comparable rates for women and men, while women were among those maintained at the highest fees in both asylums (see Table 4.3). Women and men at Highfield and Hampstead, meanwhile, had almost equal chances of being maintained at over $£ 100$ per annum

Table 4.2 Known maintenance fees by gender of paying patients admitted to Belfast, Ennis, Enniscorthy and Richmond district asylums, 1868-1900a

\begin{tabular}{lllllll}
\hline Fees per annum & Male & $(\%)$ & Female & $(\%)$ & Total & $(\%)$ \\
\hline$£ 12$ or less & 93 & 36.8 & 70 & 35.0 & 163 & 36.0 \\
$£ 12-£ 20$ & 68 & 26.9 & 77 & 38.5 & 145 & 32.0 \\
Over $£ 20$ & 92 & 36.4 & 53 & 26.5 & 145 & 32.0 \\
Total & 253 & 100.0 & 200 & 100.0 & 453 & 100.0 \\
\hline
\end{tabular}

Compiled from Belfast, Enniscorthy and Richmond Minute Books, Enniscorthy and Richmond superintendent's notices and Belfast, Ennis, Enniscorthy and Richmond admissions registers

${ }^{a}$ Maintenance fees are recorded for $65.1 \%$ of the sample

Table 4.3 Known maintenance fees by gender of first admissions to Bloomfield and Stewart's, 1868-1900a

\begin{tabular}{lllllllll}
\hline \multirow{2}{*}{ Fees per annum } & \multicolumn{2}{l}{ Bloomfield } & \multicolumn{7}{c}{ Stewarts } \\
\cline { 2 - 9 } & Male & $(\%)$ & Female & $(\%)$ & Male & $(\%)$ & Female & $(\%)$ \\
\hline Free & 4 & 4.9 & 2 & 1.4 & 0 & 0.0 & 0 & 0.0 \\
Under 20 & 0 & 0.0 & 0 & 0.0 & 0 & 0.0 & 2 & 1.0 \\
$20-25$ & 1 & 1.2 & 0 & 0.0 & 0 & 0.0 & 6 & 2.9 \\
$26-40$ & 5 & 6.2 & 6 & 4.1 & 8 & 6.4 & 17 & 8.1 \\
$41-60$ & 8 & 9.9 & 8 & 5.4 & 98 & 78.4 & 168 & 80.0 \\
$61-100$ & 9 & 11.1 & 28 & 18.9 & 17 & 13.6 & 16 & 7.6 \\
$101-150$ & 19 & 23.5 & 52 & 35.1 & 2 & 1.6 & 0 & 0.0 \\
$151-200$ & 35 & 43.2 & 51 & 34.5 & 0 & 0.0 & 1 & 0.5 \\
$201-240$ & 0 & 0.0 & 1 & 0.7 & 0 & 0.0 & 0 & 0.0 \\
Total & 81 & 100.0 & 148 & 100.0 & 125 & 100.0 & 210 & 100.0 \\
\hline
\end{tabular}

Compiled from Bloomfield and Stewarts admissions registers and financial accounts

${ }^{a}$ Maintenance fees are recorded for $89.4 \%$ of first admissions to Bloomfield and $74.2 \%$ of first admissions to Stewarts 
in these asylums (see Table 4.4). Maintenance fees for those admitted to St John of God's are not recorded, though as seen in Chap. 3, this asylum reportedly charged its all-male patient population between approximately $£ 50$ and $£ 150$ per annum, underscoring a market for less expensive asylum care for men. These findings highlight wealthier Irish families' readiness to pay significant sums towards the care of their female-as well as male-relatives.

Table 4.4 Known maintenance fees by gender of first admissions to Hampstead and Highfield, 1868-1900a

\begin{tabular}{lllllll}
\hline Fees per annum & Male & $(\%)$ & Female & $(\%)$ & Total & (\%) \\
$£ 26-£ 50$ & 0 & 0.0 & 1 & 4.8 & 1 & 2.6 \\
$£ 50-£ 100$ & 2 & 11.1 & 2 & 9.5 & 4 & 10.3 \\
$£ 100-£ 200$ & 9 & 50.0 & 7 & 33.3 & 16 & 41.0 \\
$£ 200-£ 300$ & 4 & 22.2 & 8 & 38.1 & 12 & 30.8 \\
Over $£ 300$ & 3 & 16.7 & 3 & 14.3 & 6 & 15.4 \\
Total & 18 & 100.0 & 21 & 100.0 & 39 & 100.0 \\
\hline
\end{tabular}

Compiled from Hampstead and Highfield admissions registers and financial accounts

${ }^{a}$ Maintenance fees are recorded for $11.9 \%$ of first admissions to Hampstead and Highfield

Table 4.5 Known marital status by gender of first admissions to the case studies, 1868-1900 and in the Irish census, 1871-1901

\begin{tabular}{|c|c|c|c|c|c|c|c|c|c|}
\hline \multirow[t]{2}{*}{ Asylum } & \multicolumn{3}{|c|}{ Married (\%) } & \multicolumn{3}{|c|}{ Single (\%) } & \multicolumn{3}{|c|}{ Widowed (\%) } \\
\hline & Male & Female & Total & Male & Female & Total & Male & Female & Total \\
\hline $\begin{array}{l}\text { Paying } \\
\text { patients } \\
\text { in district } \\
\text { asylums }\end{array}$ & 26.0 & 30.9 & 28.0 & 70.0 & 55.6 & 64.2 & 4.0 & 13.5 & 7.8 \\
\hline Stewarts & 22.4 & 25.8 & 24.5 & 73.3 & 57.8 & 63.9 & 4.2 & 16.4 & 11.6 \\
\hline Bloomfield & 28.9 & 36.3 & 33.6 & 62.2 & 52.8 & 56.1 & 8.9 & 11.0 & 10.3 \\
\hline $\begin{array}{l}\text { St John of } \\
\text { God's s }\end{array}$ & 27.1 & 0.0 & 27.1 & 67.6 & 0.0 & 67.6 & 5.3 & 0.0 & 5.3 \\
\hline $\begin{array}{l}\text { Hampstead } \\
\text { and } \\
\text { Highfield }\end{array}$ & 42.1 & 42.6 & 42.3 & 52.8 & 49.1 & 51.5 & 5.1 & 8.3 & 6.2 \\
\hline Irish census & 27.4 & 27.0 & 27.2 & 68.8 & 63.5 & 66.1 & 3.9 & 9.5 & 6.7 \\
\hline
\end{tabular}

Compiled from Belfast, Ennis, Enniscorthy, Richmond, Stewarts, Bloomfield, St John of God's and Hampstead admissions registers 1868-1900; Irish Historical Statistics: Population, 1821-1971, W.E. Vaughan and A.J. Fitzpatrick (eds.) (Dublin, 1978), pp. 88-89

aThe first admission to St John of God's was in 1885 
Table 4.6 Maintenance fees by gender by marital status of first admissions to the case studies, 1868-1900

\begin{tabular}{lllllllll}
\hline \multirow{2}{*}{ Fees } & \multicolumn{2}{l}{ Female (\%) } & \multicolumn{7}{c}{ Male (\%) } \\
\cline { 2 - 9 } & Married & Single & Widowed & Total & Married & Single & Widowed & Total \\
\hline Less than $£ 50$ & 64.0 & 71.1 & 66.2 & 68.3 & 72.4 & 77.4 & 63.6 & 75.5 \\
$£ 51-£ 100$ & 9.3 & 10.1 & 14.3 & 10.4 & 11.2 & 7.8 & 9.1 & 8.8 \\
$£ 100-£ 200$ & 23.8 & 17.6 & 18.2 & 19.6 & 14.7 & 13.2 & 27.3 & 14.2 \\
More than $£ 200$ & 2.9 & 1.3 & 1.3 & 1.8 & 1.7 & 1.6 & 0.0 & 1.5 \\
Grand total & 100.0 & 100.0 & 100.0 & 100.0 & 100.0 & 100.0 & 100.0 & 100.0 \\
\hline
\end{tabular}

Compiled from Belfast, Ennis, Enniscorthy and Richmond admissions registers, minute books and superintendent's notices

Being married or single had further implications for the amounts contributed towards maintenance. While Malcolm has found that district asylum patients of both sexes were more likely to be single, reflecting 'the trend towards celibacy strongly evident in the general Irish population after the Famine', Cox has shown that single men during this period were 'particularly vulnerable to institutionalisation' in district asylums, a trend which she identifies as pre-dating declining marriage rates in Irish society and being linked to the use of dangerous lunatic certification. ${ }^{17}$ Between 1826 and 1867, patients committed to Bloomfield (62\%) and Hampstead $(62.2 \%)$ were more often single. Single men were more likely to be committed to Hampstead and single women to Bloomfield. The marital status of first admissions changed little in the second period. Table 4.5 indicates that from 1868 to 1900 there was a predominance of single first admissions to all the asylums studied. However, except for Hampstead House, these figures were close to average for the population of Ireland. In fact, bachelors were underrepresented among first admissions to Bloomfield, Hampstead and St John of God's, deviating from the profile of district asylum populations in Ireland.

The story is similar for women admitted to the asylums. Apart from Stewarts, married women were over-represented, implying wives were more vulnerable to committal, especially to expensive asylums. This predominance of husbands and wives deviates from English contexts, where there was a preponderance of single women admitted to Ticehurst and over two-thirds of woman admitted to Wonford House private asylum near Exeter were single. ${ }^{18}$ Digby has found that wives were also less 


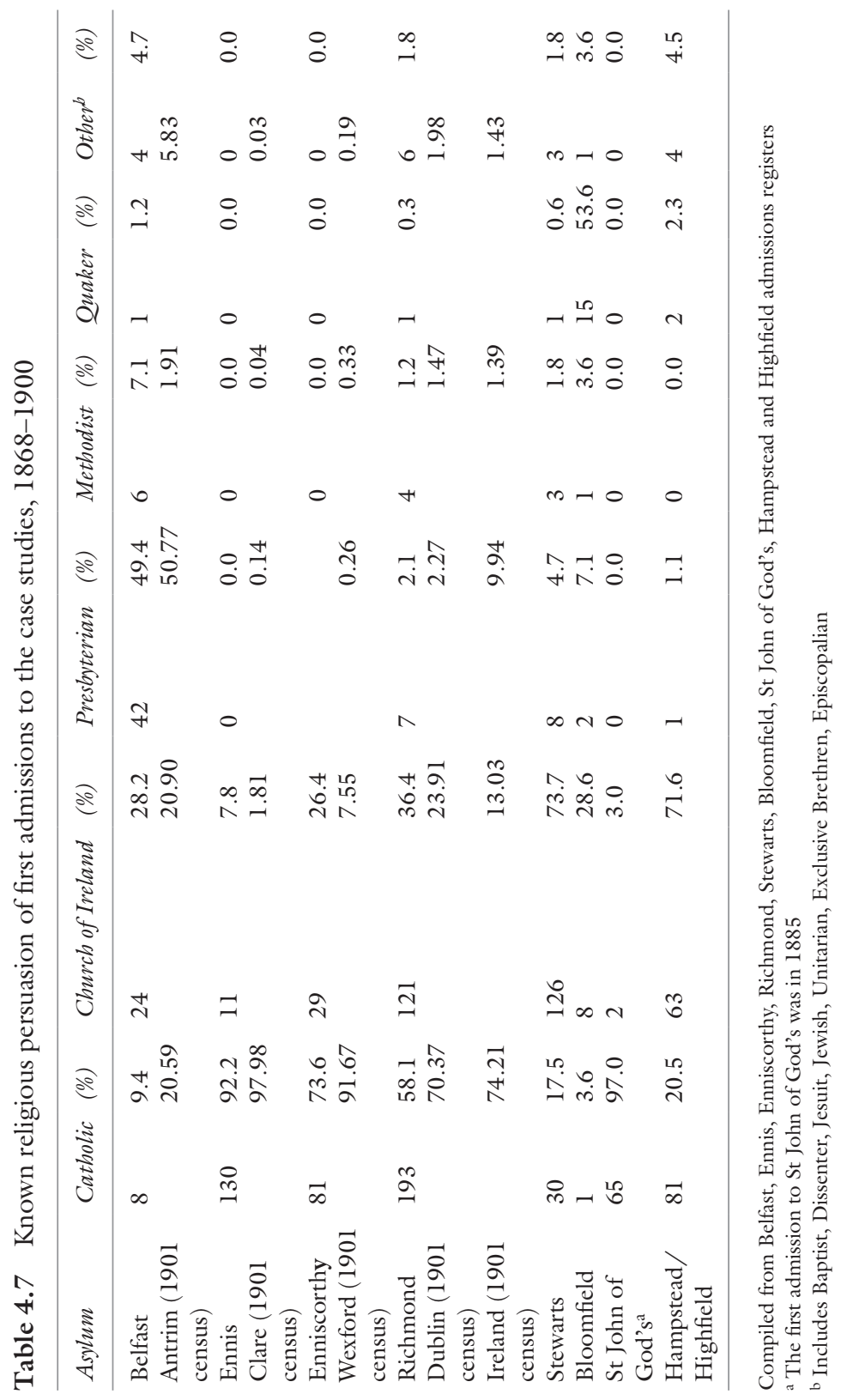




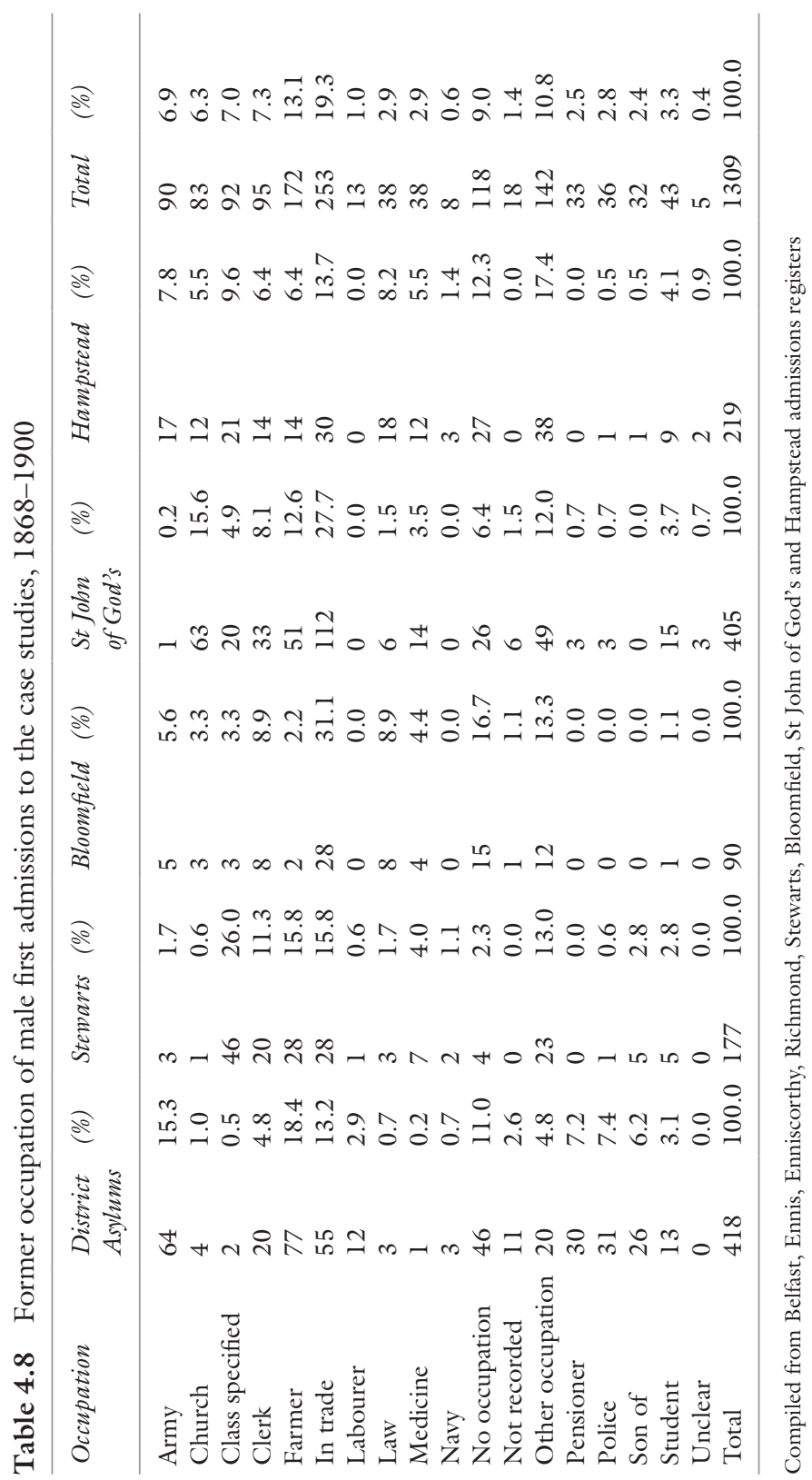


Table 4.9 Known maintenance fees for male farmer first admissions to Belfast, Ennis, Enniscorthy and Richmond district asylums, 1868-1900

\begin{tabular}{llllllllllll}
\hline $\begin{array}{l}\text { Feesper } \\
\text { annum }\end{array}$ & Belfast & (\%) & Ennis & (\%) & Enniscorthy & (\%) & Richmond & (\%) & All & (\%) \\
\hline $\begin{array}{l}\text { Less than } \\
£ 12\end{array}$ & 1 & 50.0 & 19 & 76.0 & 3 & 17.6 & 3 & 37.5 & 26 & 50.0 \\
$£ 12-£ 20$ & 1 & 50.0 & 4 & 16.0 & 7 & 41.2 & 0 & 0.0 & 12 & 23.1 \\
Over $£ 20$ & 0 & 0.0 & 2 & 8.0 & 4 & 41.2 & 5 & 62.5 & 14 & 26.9 \\
\end{tabular}

Compiled from Belfast, Ennis, Enniscorthy and Richmond admissions registers, minute books and superintendent's notices

prone to committal to the York Retreat, possibly reflecting their responsibility for children and the household. Interestingly, Digby characterises this finding as 'a thought-provoking corrective to contemporary alarmist literature on asylums, which often emphasised the abuses of vengeful husbands wrongfully confining sane wives'. ${ }^{19}$ By extension, it could be held that the over-representation of married women in some of Ireland's more expensive asylums reveals a tendency towards the 'wrongful confinement' of wealthy Irishmen's wives. Certainly, husbands paid the fees for $67.9 \%$ of wives committed to Stewarts. ${ }^{20}$ However, there is no qualitative evidence to support this. Moreover, as Chap. 5 contends, spouses and other family members often demonstrated affection and care for their mentally ill relatives, casting some doubt on the extent to which wrongful confinement occurred. ${ }^{21}$

Male heads of families and adult relatives tended to be maintained at lower fees than female ones, reflecting men's greater economic significance in their households. With the loss of their incomes, it is plausible that remaining members of the family struggled to pay high fees. This contrasts with the arguments put forward by Walsh and MacKenzie that families were more willing to invest in the care of male breadwinners ${ }^{22}$ and suggests that the relatives of married male patients had less disposable income to contribute towards asylum care (Table 4.6).

As we have seen, the relatives of district asylum patients sometimes went to great lengths to contribute maintenance fees, even borrowing money and falling into debt. The wealthier families of voluntary and private asylum patients also paid directly for relatives' care. ${ }^{23}$ The financial accounts for Stewarts indicate the relationship between patients and those who paid their fees. Relatives were by far the most common 
creditors: a single relative contributed fees for $68.7 \%$ of first admissions, two relatives for a further $6.8 \%$, a relative and friend for $3.7 \%$ and a relative in conjunction with a Chancery fund for $0.9 \%$. 'Friends' accounted for another $6.8 \%$, although this figure may be higher as a handful of the names recorded in the financial accounts did not include their relation to the patient $(4.3 \%)$. In contrast, very few Stewarts patients paid their own fees out of an income. A Chancery fund alone accounted for $6.8 \%$, one patient paid her fees from the Dublin Widow's Fund, one from the War Office and two from dividends on stock they possessed.

The predominance of relatives covering fees at Stewarts (80.2\%) and the large number paying for patients at Bloomfield, Hampstead and Highfield who shared their surname, demonstrates that families in Ireland were willing to pay for their relatives' care. ${ }^{24}$ Whether this was simply to get rid of a difficult household member or a genuine attempt to seek treatment in the hope of a cure is unclear. What can be inferred is that a large proportion of paying patients - even those who were unmarried-were part of an often large, family network. Cox has highlighted the presence of mentally ill adult offspring in family households, which, she suggests indicates that 'relatives with some legal obligation undertook a caring role'. ${ }^{25}$ In this study, the very fact that families paid for the care of their relatives corroborates these findings.

Record linkage with the census records casts further light on the familial contexts of paying patients. Out of twenty-nine patients discharged from the asylums studied between 1898 and 1900 who could be identified in the 1901 census, none returned to an empty home. ${ }^{26}$ Johanna R., previously a paying patient at Enniscorthy, lived with her widowed sister-in-law and this woman's eight children. More typically, when Hannah B., an unemployed schoolteacher, was discharged from Highfield, she returned to live with her father (a railway clerk), her mother, two brothers (a railway clerk and hardware merchant's clerk) and one sister. However, a minority had apparently broken ties with their previous households. Six discharged patients were no longer at their previous address in 1901 and one was in a boarding house. Margaret D., a fifty-nine-year-old retired schoolteacher, was admitted to and discharged from Richmond in 1898 from an address in Dublin. By 1901, Margaret no longer lived at the address, which housed a married couple in their fifties (sharing Margaret's surname) and their teenage niece. This implies that prior to committal, Margaret had been living with her younger brother (who is mentioned in the case notes) and his wife, who had or 
soon would take custody of the niece. It is plausible that this household unit found itself incapable of caring for more than one dependent, which would account for Margaret's move following discharge. A property Margaret owned had become a source of tension between herself and her brother and sister-in-law, suggesting that this may also have played a role in her change of address following discharge. ${ }^{27}$

This section has demonstrated that where gender and marital status were concerned, fee-paying patients were similar to total district asylum populations. There is danger, however, in discussing such diverse patient populations simply in terms of demographic trends. Rather than forming a single cohesive group, each patient emerged from a distinctive family unit-some were breadwinners, some adult dependents. That many of these families struggled to cope without their breadwinner's income or to drum up enough financial support to provide 'class-appropriate' care for a dependent is probable. In fact, evidence of the financial sacrifices families made to pay for asylum care casts doubt on the extent to which relatives tended to 'dump' their female, their single or their 'unwanted'. ${ }^{28}$

\section{Religion, Occupation and Wealth}

Lorraine Walsh has cautioned against directly associating patients' former occupation with social status, arguing that on admission, patients were labelled and classified based purely on their own or their relatives' and friends' spending power, while their class or social status meant little. ${ }^{29}$ In her analysis of private patients at the Dundee Royal Asylum in Scotland, Walsh highlights the difficulties in accurately constructing 'a system of commensurability' between occupation and status. ${ }^{30}$ Analysis of patients' occupations alongside maintenance fees, however, facilitates direct correlation between particular professional groups and their families' spending power. In the Irish context, patients' religious affiliation is also of interest as it formed an integral part of social identity in this era. Patients' religious denomination therefore reveals much about the sectors of society admitted to the asylums studied. It is useful, too, to consider what parts of Ireland (or abroad) patients in the study were drawn from.

District asylums were intended to provide care for people of the same district. Paying patients were therefore usually committed to the asylum in the county in which they had lived. Thus, Belfast patients came from 
Antrim, Ennis patients from Clare or less often neighbouring Limerick (9.4\%) and Enniscorthy patients from Wexford. The Richmond district was larger and admitted paying patients from Dublin (85.3\%) and neighbouring counties Louth (7.6\%) and Wicklow (6.7\%). Roughly, half of those admitted to the voluntary and private asylums studied had a previous residence in Dublin, while the other half were from various other Irish counties. ${ }^{31}$ This indicates that these Dublin-based voluntary and private asylums served the whole of Ireland and many patients would have travelled large distances to receive care. In her study of Ticehurst, MacKenzie attributes families' willingness to send patients long distances for care to a 'desire for confidentiality'. ${ }^{32}$ While this might be the case for Ireland, it is important to remember that there were few private asylums outside Dublin, meaning that wealthier families had little option but to send their relatives to the capital.

The religious profile of paying patients speaks volumes about the impact the religious character of institutions had on committal patterns. Apart from Belfast, paying patients committed to the district asylums studied were far more likely to be Catholic than those sent to the voluntary or private asylums (see Table 4.7). ${ }^{33}$ This excludes St John of God's which, as we have seen, was managed by a Catholic order of brothers and therefore admitted mainly Catholics (97\%). Compared with the general population of Ireland, patients in this study, except for those at St John of God's, were disproportionally members of the Church of Ireland, while Catholics were underrepresented. The reasons for this could vary. The over-representation of Church of Ireland patients admitted to most asylums in this study suggests that Protestant communities in nineteenth-century Ireland could better afford to purchase asylum care. Predictably, there was a preponderance of Quakers admitted to Bloomfield (53.6\%), at odds with the number outside. Catholic admissions were in a minority at Bloomfield, equalling Methodists and Brethren and outstripped by Presbyterians. In keeping with its Protestant ethos, almost three-quarters of the patients admitted to Stewarts were members of the Church of Ireland, compared with less than one-quarter being Catholic.

As Chap. 3 outlined, varying rates of maintenance signified social diversity within and between asylum populations. Examining patients' former occupations alongside their maintenance fees further supports this position. Beginning with male first admissions to the asylums studied, Table 4.8 provides a crude breakdown of their former occupations. ${ }^{34}$ 
The most prominent category was 'in trade', which is unsurprising, given that many industries and crafts were on the rise in late nineteenth-century Ireland. ${ }^{35}$ Among paying patients admitted to the district asylums, the highest proportion of trades-craftsmen was in Belfast $(24.4 \%)$, which included dealers in unspecified goods, printers, drapers, boot and shoemakers, businessmen, merchant tailors and linen merchants. This sits well with industrial Belfast's expanding linen and shirt-making industries in the later nineteenth century. ${ }^{36}$ In contrast, the proportion of tradesmen in Ennis was far lower (3.4\%) and comprised only one car man, three shopkeeper's sons and two of the 'trading class'. With the exception of one man whose maintenance was $£ 20$ per annum, the remainder of this cohort were charged modest sums $(£ 6-£ 12)$.

In keeping with Wexford's stronger trade element, trade was the second most common occupation (21.3\%) after farming for male paying patients in Enniscorthy. This group comprises an equally wide range of occupations including bakers, builders, carpenters, coopers, drapers, painters, printers, saddlers, shoemakers, shopkeepers and tailors. The Enniscorthy case notes often indicated that these patients were business owners. For example, one patient owned a draper's shop on Wexford town's Main Street. On other occasions, patients simply worked in a shop, as was the case with Thomas G., a baker.

For the period 1868-1900, Richmond admitted a relatively small proportion of trades-craftsmen as paying patients (12.6\%). These patients represented a disparate range of trades and crafts including bakers, carpenters, cashiers, chefs, draper's assistants, grocers or shopkeepers, linen coopers, merchants and victuallers. Shopkeepers and grocers were the most prominent in this category, although even they comprised only about $2 \%$. Similarly, only about $5 \%$ of those admitted to the private and voluntary asylums fell into this category. The absence of patients from Dublin's brewing and distilling industries is particularly noteworthy, given the rising importance of the Guinness Brewery and Powers Distillery during the period. ${ }^{37}$ Despite the prominence of baking, textiles and, to a lesser extent, dressmaking in late nineteenth-century Dublin, ${ }^{38}$ very few of Richmond's paying patients, or those sent to the voluntary or private asylums, had engaged with these industries, implying that the relatives of a number of Dublin's most common tradesmen could not afford asylum care.

Patients described as travellers, merchants or dealers were charged between $£ 24$ and $£ 27$ per annum at Richmond and were most 
commonly found in voluntary or private asylums. Out of male admissions to Bloomfield and Hampstead, $7.9 \%$ and $6.4 \%$ respectively were merchants. That a large proportion of Bloomfield's admissions were in trade may be attributable to traditional links between Quakerism and the merchant trade, although the religion of merchants in Bloomfield was not recorded in most cases. Shopkeepers and grocers also featured more prominently among patients in voluntary and private asylums, suggesting that the families of these men, together with merchants, had greater disposable income to spend on asylum care.

Farmers in this study are relatively well represented across the board. The predominance of farmers (13.1\%) in the asylums studied is unsurprising, given their growing importance during the second half of the nineteenth century. After the Famine (c. 1845-1850), many Irish farmers prospered and on the whole rural incomes increased. ${ }^{39}$ In the later nineteenth century, the number of landless labourers declined and larger farms became more common. ${ }^{40}$ Above the grade of small farmers, who can be broadly characterised as those holding at least five acres of land, David Seth Jones has identified another group, which he terms graziers: those who occupied at least one holding of 150-200 acres. $^{41}$ Between small farmers and graziers, the smaller tenants and cottiers who decreased in number during the Famine (c. 1850) were replaced by the more successful, middle-class farmer. ${ }^{42}$

While the asylum records do not facilitate a full statistical breakdown of the varying grades of farmers catered for, they do allow some glimpses. Of the 172 farmers sent to the nine selected asylums, 155 were recorded simply as 'farmer'. Others under this heading included a farmer and miller, a farmer who owned a shop, seven 'gentlemen' farmers, three graziers and one small farmer. The small number of graziers probably stems from inconsistencies in the asylums' recording processes, though it is significant that they appear only in the private asylums, St John of God's and Hampstead, signalling the higher spending power of this group and their families. The only 'small farmer' in this study was admitted to Richmond, while all but one of the gentlemen farmers were admitted to private asylums, with the other admitted to Enniscorthy.

An analysis of farmers' maintenance fees further underscores the wide socio-economic variation within this group. The majority of known fees for farmers are for those admitted to the district asylums. Table 4.9 reveals that there were significant differences between each district. County Wexford was traditionally one of the wealthier farming areas in 
Ireland and boasted many large estates as well as smaller holdings. ${ }^{43}$ This is reflected in the fees paid for farmers at Enniscorthy, which are distributed quite evenly between the three categories. Enniscorthy also had the smallest proportion of farmers paying less than $£ 12$. At Ennis, more than three-quarters of farmers were maintained at less than $£ 12$, reflecting the difficult economic circumstances experienced by many in the west of Ireland. ${ }^{44}$ While in earlier periods the landlord class was the smallest, but economically most significant, group in rural Irish society, the Land Wars of the 1880s diminished the significance of this social group, resulting in the rising importance of Catholic landowners. ${ }^{45}$ Farmers maintained at over $£ 20$ per annum in Ennis were exclusively Catholic, suggesting that this group preferred to commit relatives to the local district asylum rather than sending them to private or voluntary institutions in distant Dublin. In contrast, at Enniscorthy, more than half the farmers accommodated at over $£ 20$ were Protestant. Richmond also tended to cater for more successful farmers although a smaller, but significant, proportion $(37.5 \%)$ was maintained at $£ 12$ or less.

Farmers' acreage is another useful indicator of their socio-economic status. At Enniscorthy, Drapes sometimes recorded patients' farm acreage in his case notes on patients admitted in the 1890s. For example, Drapes noted that Patrick D.- - a single fifty-eight-year-old Catholiclived alone on his farm of seventeen acres. At the other end of the scale, Drapes wrote that Francis R., a single fifty-three-year-old Catholic farmer, had told him he had a farm of 110 acres. ${ }^{46}$ Drapes usually recorded land acreage for female paying patients, suggesting that this was an important factor in determining their social status and financial circumstances. In some cases, Drapes detailed the land of the spouse or sibling responsible for the woman's maintenance. For example, when Hannah N. was sent to Enniscorthy aged forty and single, Drapes noted that her two living brothers, Thomas and James, 'each has over 90 acres (pt. sup) and James a mill as well' ${ }^{47} \mathrm{He}$ also recorded the acreage of patients who were farmers' wives. Among these, he wrote that Catherine $S$. had twenty-eight acres, Anne J. had forty-eight acres, reputedly worth $£ 46$ and Margaret Sara K. had 100 acres. ${ }^{48}$ Marcella J.'s son had a farm of thirty acres and Marcella also sold her chickens on market day. ${ }^{49}$ Of these examples, only Margaret Sara K. was a Protestant, mirroring the fact that Protestant landowners tended to retain the larger estates. However, Johanna F., a Catholic, was reportedly the niece of a man from New Ross who owned a farm of 200 or 300 acres. ${ }^{50}$ Likewise, the 
Table 4.10 Relationship between land acreage and maintenance fees charged for paying patients admitted to Enniscorthy district asylum, 1868-1900

\begin{tabular}{ll}
\hline Fee per annum & Holding size \\
\hline$£ 8$ & 20 acres of a farm \\
$£ 12$ (later reduced to $£ 8)$ & 28 acres \\
$£ 13$ & 30 acres free \\
$£ 15$ & 48 acres valued at $£ 46$ \\
\hline
\end{tabular}

Compiled from Clinical Record Volumes No. 3, 4 \& 6 (WCC, St Senan's Hospital, Enniscorthy); Enniscorthy minute books and admissions registers

examples of the male patients above demonstrate that Catholic farmers in Wexford could occupy both ends of the social scale.

Finally, in four cases, both the amount of land owned and the maintenance fees for Enniscorthy paying patients were recorded. As Table 4.10 demonstrates, acreage was roughly proportionate to the fees charged, indicating landholding size was a determining factor for maintenance fees. As this table reveals, even the lowest grade of paying patient at Enniscorthy $(£ 8)$ could possess twenty acres, placing them well above the defining lower limit of small farmer (five acres). If these values are taken as representative, several paying patients from the farming classes could be termed part of the rising Catholic middle classes.

Those under the heading 'other occupation' comprise a medley of professions that defy any systematic classification. Predictably, several of the 'other occupations' pursued by men admitted to voluntary and private asylum tended to be professionals rather than tradesmen. Among them were white-collar workers like engineers, stockbrokers, bank managers, architects, bookkeepers and accountants. Together with clerks, members of these professions made up a large proportion of admissions to voluntary and private asylums and were usually members of the Church of Ireland. ${ }^{51}$ This conforms to Daly's assertion that Protestants numbered disproportionately among the 'middle-class occupations' of professional and public service and the white-collar clerical and banking jobs in this era. ${ }^{52}$ However, it is important to bear in mind that, with the exception of St John of God's, the voluntary and private asylums in this study were primarily populated by Protestants.

The proportion of men recorded as having 'no occupation' varied widely from one asylum to the next, reflecting discrepancies in record 
keeping. The highest numbers of male first admissions in this category were in district asylums (11\%) and at Hampstead (12.3\%), while 'unemployment' was lowest among men sent to Stewarts (2.3\%) and St John of God's (6.4\%). For Stewarts' patients, explanation for the low proportion described as having 'no occupation' might lie in the tendency to enumerate patients' social class rather than occupation; almost one-quarter of male first admissions were described as 'gentlemen'. However, 9.6\% of men admitted to Hampstead were also described in terms of their social class (mostly gentlemen), suggesting that an even larger proportion of admissions to that asylum were without a particular occupation. The category of 'no occupation' therefore encompassed a wide range of social groups from the unemployed to those with independent means and maintenance fees for this group ranged from $£ 6$ to $£ 213$ per annum. Those kept at the highest rates were probably wealthy gentlemen. Certainly, in 1857, the lunacy inspectors surmised that the large proportion of private asylum patients recorded as having no occupation were mainly comprised of 'persons of independent fortune'. ${ }^{33}$ In addition, it is plausible that at least some of this cohort would have been landlords. ${ }^{54}$

A final group worthy of mention is those in the army. Although not well represented in the voluntary and private asylums, soldiers were the second largest category committed to the district asylums as paying patients. This is mostly due to Richmond, where $28.3 \%$ of male paying patients admitted were soldiers. A small but notable proportion of soldiers were sent to Bloomfield (5.6\%) and Hampstead (7.8\%). Unsurprisingly, soldiers sent to Bloomfield and particularly Hampstead were from the higher ranks of the army, such as captains or lieutenants, while those committed to Richmond were more often described as privates or simply soldiers, in addition to a handful of army pensioners. The high proportion of soldiers admitted to Belfast (10.6\%) and Richmond stems from these asylums' proximity to prominent army barracks.

The Richmond case notes provide insight into the committal and discharge of soldiers at that asylum. The military authorities took responsibility for the committal, maintenance charges and discharge of these soldiers. Accordingly, the authority of the asylum medical officer or superintendent was lessened, even in cases where they suspected a patient was not mentally ill. In several cases, the reporting physician noted his suspicion that a soldier patient was malingering in the hope of being discharged from service. By 1901, suspicions of malingering at Richmond had even spread to the patient population and a female paying patient 
remarked that 'Dr. Rambant [Richmond medical officer] has a lot of military fellows on getting what the patients should get. Talks of someone (the military fellows I suppose) humbugging the doctors behind their backs. ${ }^{55}$ In earlier case notes, the medical officers were conscious that at least some of the soldiers admitted were apparently in good mental health, although they did not state this explicitly. The first instance occurred in 1890, when Robert B. was admitted. Dr. M.J. Nolan, the Senior Assistant Medical Officer to the Richmond Asylum, reported:

He seems anxious to attract attention of the medical officers by his conduct - when they are not present he is reported to be quiet and orderly ... Is anxious to know whether he has altogether severed his connection with the army ... Says he is very anxious to know what is to become of him whether he is to be sent home to England or left here. He says he cannot endure the conduct of the patients. ${ }^{56}$

The following year, another soldier, Charles H.R., was 'closely watched ... day and night for malingering'. Although Nolan was 'satisfied that he is not insane', he noted:

$\mathrm{He}$ is determined to secure his discharge from the service and is capable of enduring much discomfort in his effort to appear insane. He has today been handed over to the military authorities. Discharged 12 March $1891 .{ }^{57}$

When Francis B. was asked 'if he is tired of being a soldier he smiles and says he is'. Although the Army Medical Board examined him on 25 June 1891 and discharged him from service, it was not until 31 August that he was handed over to the military authorities and discharged from the asylum relieved. In the interim, Francis reportedly became 'depressed and seems disappointed that no notice has come from the military authorities concerning his removal'. When Nolan attempted to cheer him up, informing him that 'he may now be sent to England any day he only sighs, says all is over with him, that he is dead and that we mean to cut him up' ${ }^{58}$ It is conceivable that the military authorities were eager to make an example of malingering comrades by forcing Francis to remain wrongfully confined in the asylum.

In the case of Thomas H., a different medical officer was vigilant in his attempt to ascertain if the patient was insane. ${ }^{59}$ Although they were 
unable to detect malingering, the medical officer ordered the attendants to 'take special note of his behaviour but according to them he has not at any time altered in his manner'. The medical officer then decided to launch an investigation of his own:

Last night I awoke him and asked him how long he had been asleep. His manner of speaking and acting was brighter and more intelligent for the first few moments, though when he realised where he was he seemed to relapse into his usual dull stupid state. ${ }^{60}$

When the Army Medical Board examined Thomas a week later, they decided he should remain in Richmond for another month. Nolan reported that the board could not 'satisfy themselves as to his mental state'. He also noted that 'during examination he affected a dull dogged manner quite unlike his usual state'. ${ }^{61}$ In this instance, while Nolan and his fellow medical officer were clearly certain of their patient's sanity, the Army Medical Board had the final say, thus diminishing the authority of the asylum medical officers. According to Nolan, some soldier patients went to great lengths to attempt to convince asylum staff and the Army Medical Board they were unfit for duty. Nolan claimed that Thomas H. became so 'dirty' and 'untidy in his habits' that the attendants became 'satisfied he is insane'. ${ }^{62}$

While the precise reasons for these soldiers' attempts to be discharged from service remain largely obscure, asylum life was clearly a preferred alternative to the army in these cases. For example, when Leo S., a Russian Jewish soldier, was admitted in 1893 and noted as being epileptic, he quickly 'admitted that he was malingering' to escape his comrades' racial insults. He explained to Nolan that he had bought ' $4 d$. worth of salts of sorrel' to bring on the symptoms of epilepsy and that he:

shammed epilepsy because he was so miserable in the army; his comrades used to insult and bully him; chiefly on the sub [sic] of his nationality ... he had been much annoyed by the manner his comrades looked on him that he felt he 'was not wanted' ... In consequence of this he became depressed and gave way to drink and at the time he took the sorrel he was under sentence to the cells for absence from duty and it was partly to avoid this punishment he sought to make himself ill. ${ }^{63}$ 
Leo's frank confession to Nolan suggests his awareness that asylum staff had little say over his discharge from either the army or the asylum. By this point, Nolan seemed resigned to his diminished authority over soldier patients and following this he often simply noted 'insanity very doubtful. A soldier anxious to leave the army'. ${ }^{64}$

The outcome for most of these soldiers following discharge is unknown. In the case of an Irish soldier named Edward D., it is possible to conjecture. Edward informed the medical officer that 'he enlisted when drunk - that he has got a good job waiting for him if he could get out of the army but that he has no special wish to leave the service'. A month later, however, Edward changed his mind, 'says he would like to get home to his father where a good job awaits him. He has no wish to return to the Army.' Less than a month later, the patient was discharged from both the asylum and the army. He returned home where he presumably began working at the 'good job' he had mentioned to his doctor. $^{65}$

Compared with male patients, the former occupations of female paying patients provide less clear-cut indications of their socio-economic background. In this regard, the recording process varied widely in the selected asylums, reflecting the difficulties inherent in attempting to reconstruct the occupational profile of women in the nineteenth century. Women's occupations have also tended to be under-recorded in Irish censuses because work in farming and industry was often combined with family duties. The 1871 census is a notable exception; it identified farmers' wives as part of the agricultural force and wives who contributed to family businesses as being employed in them. ${ }^{66}$ As Daly has argued, census enumerators tended 'to assign women to the domestic or unoccupied class', reflecting 'society's belief that this was their appropriate place'. ${ }^{67}$ In a similar vein, Melling has shown that Victorian women were often deprived of an occupational status in the English census because their labour was not recognised as valuable in its own right. ${ }^{68}$ However, as discussed above, those filling in admissions registers for female paying patients were more concerned with ascertaining their spending power. ${ }^{69}$

Table 4.11 provides a crude breakdown of the principal occupational categories for female paying patients admitted to the selected asylums. Overall, more than three-quarters had no recorded occupation, though this varied significantly between regions and institutions. A disproportionately high percentage of 'unemployed' women were sent to Richmond and to a lesser extent, Belfast. In contrast, almost two-thirds 
of female paying patients committed to Ennis and a third of those to Enniscorthy were listed under a relatives' occupation: 'wife of', 'daughter of', and so on. The appellation 'wife of' was not peculiar to paying patients. Pamela Michael has found that female asylum patients in nineteenth-century Wales were often listed under their husband's occupation, although after marriage many may have continued to engage in paid employment that was important to family survival. ${ }^{70}$

The large proportion of 'unemployed' women committed to Bloomfield and Highfield is expected, given that Irish middle-class women and even some in skilled working-class families tended not to work outside the home. ${ }^{71}$ Stewarts' female patients were far less often described as having 'no occupation' but, instead, just over half were labelled in terms of their social status. Of these, most $(47 \%$ of total female admissions) were termed a 'lady', compared with only $9.8 \%$ of the women committed to the more expensive Bloomfield. At Bloomfield, 'ladies' were maintained at between $£ 100$ and $£ 180$ per annum, while at Stewarts more than three-fifths were maintained at less than $£ 50$ and some as low as $£ 20$. Those described as 'lower order', 'mid class' or 'middle' were also maintained at less than $£ 50$. These discrepancies highlight the fluidity of labels like 'lady' and 'middle class' and demonstrate the pitfalls of blindly interpreting them as representative of social class or spending power.

Women committed to Belfast, Richmond and Stewarts asylums were most often assigned designated occupations in the admissions registers. This reflects urban trends. Despite a national decline in female employment in the Irish labour force from 1861, particularly in Connaught and parts of Leinster, the highest proportions of working women were in Counties Antrim, Armagh and Down and urban areas such as Dublin City and its suburbs. ${ }^{72}$ During the nineteenth century, the north-east rivalled areas such as Lancashire in terms of the high proportion of women working in factories. ${ }^{73}$ Nonetheless, with the exception of two dressmakers, one upholsterer and one weaver, there is little evidence of Belfast paying patients' participation in Ulster's strong textile and clothing sectors. ${ }^{74}$ Likewise, although dressmaking was the most popular occupation among female industrial workers in Dublin, ${ }^{75}$ Richmond admitted only one court dressmaker, draper, dressmaker and embroiderer as paying patients. While it is possible that some of these women were engaged in factory work, it is equally, if not more, likely that they carried out these occupations in the home. 


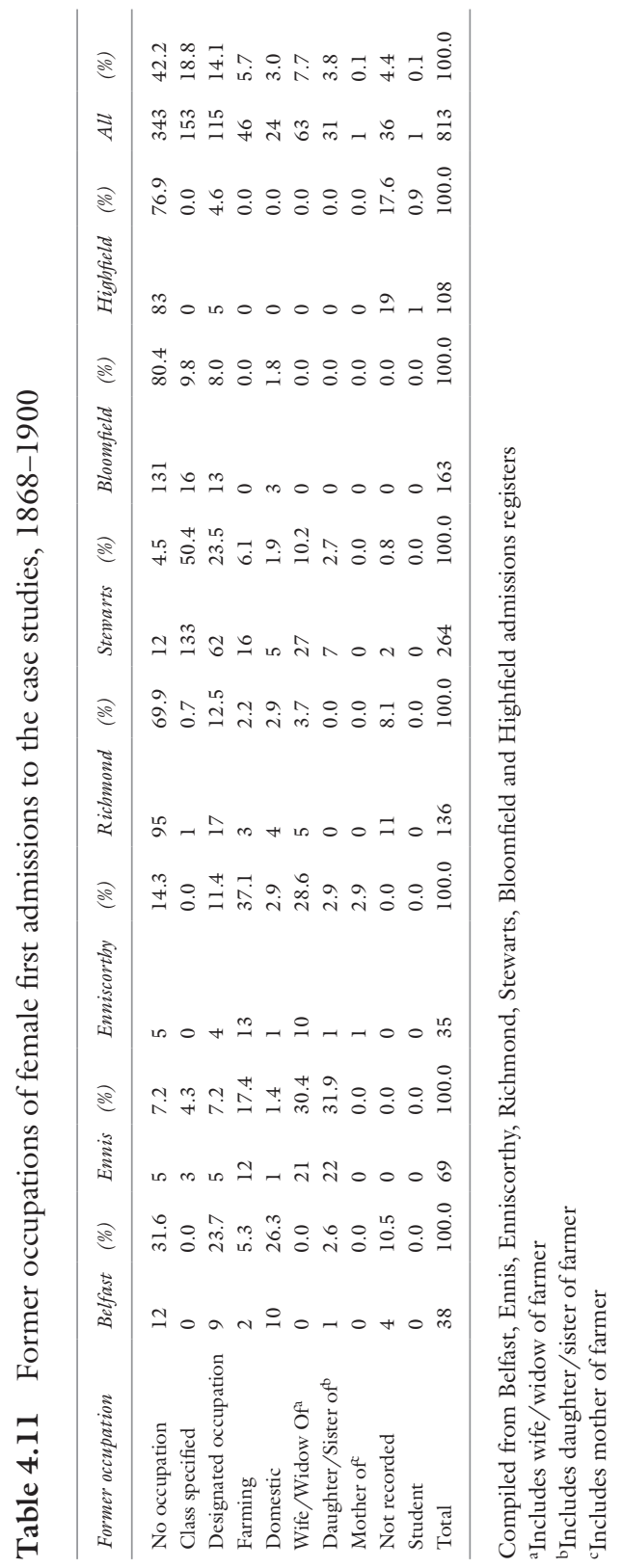




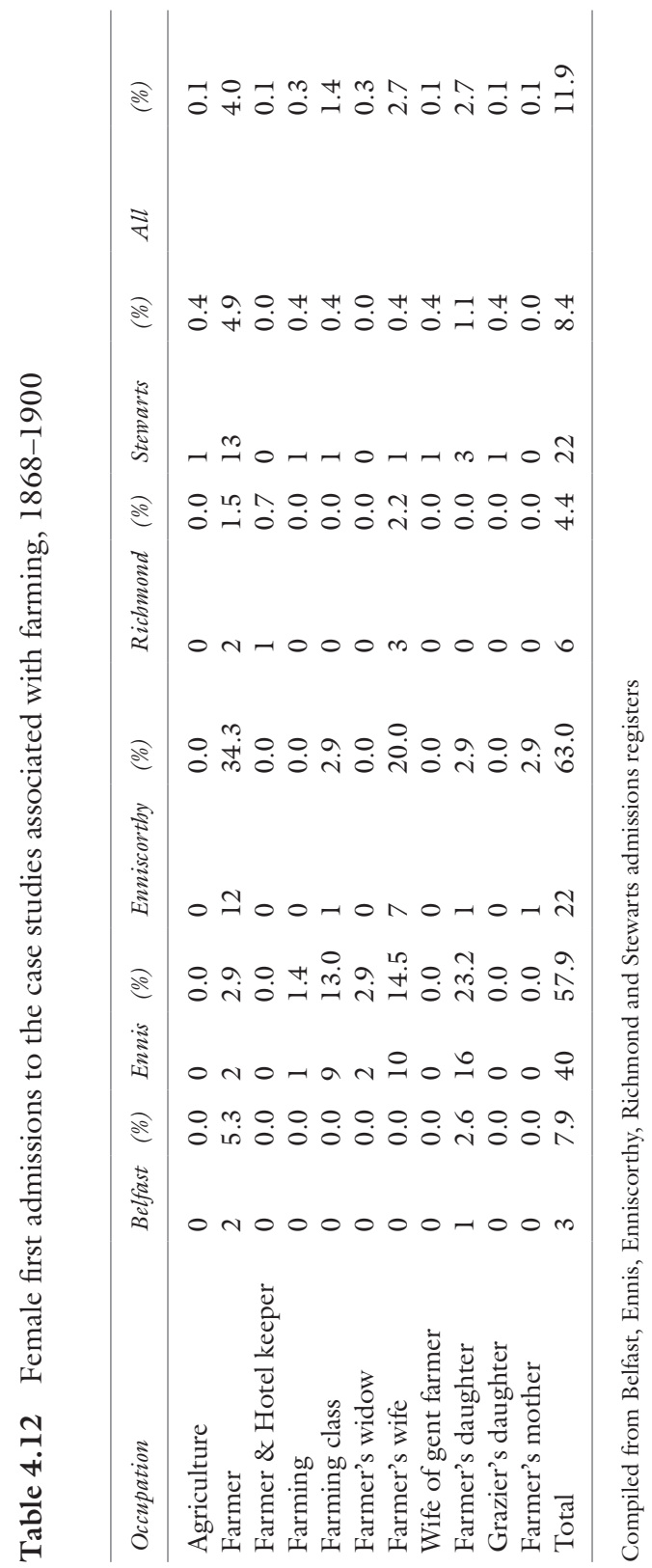


As Daly has argued, aside from a small number of female professionals and commercial clerks, women with recorded occupations in the census were poor. ${ }^{76}$ Yet, in this study, women assigned occupations in the admissions registers were not necessarily maintained at low rates, suggesting that their relatives had at least a degree of spending power. Some were accommodated at as much as $£ 160$ per annum. Designated occupations included nuns, teachers, governesses, shopkeepers, shop assistants and shop girls, servants, grocers, nurses and those who worked with textiles. This list is indicative of women's rising opportunities in the workplace towards the end of the nineteenth century. Shop assistants, in particular, were perceived by contemporaries as representative of 'women's altered role in the public sphere' and this group was by no means among the poor. From the mid-nineteenth century, shop assistants had been 'manoeuvring towards membership of the Irish petit bourgeoisie' and, by the twentieth century, female shop assistants, drapers and draper's assistants clearly enjoyed a new brand of economic independence. ${ }^{77}$ The recording of occupations for female paying patients in this study therefore does not necessarily indicate poverty.

For several women in lower paid professions, poverty, particularly following the onset of mental illness, was more likely. As Melling has found in his study of governesses and female schoolteachers admitted to three Devon asylums, while their domestic means could be modest, it was vital for this social cohort to avoid the publicity of their committal. Melling demonstrates that 'many private teachers relied on connections with the "best circles" and 'were understandably anxious to maintain some proximity to the privileged world of their employers' ${ }^{78}$ Melling also argues that relatives and friends often strove to avoid committing governesses to pauper institutions and struggled to finance their accommodation at private asylums such as Wonford House. ${ }^{79}$ These findings might account for the presence of governesses, schoolteachers and even domestic servants in the voluntary asylums in this study. However, this study suggests that employers, rather than relatives, paid for their maintenance, a privilege they also extended to domestic servants. In Bloomfield, an unidentified source contributed $£ 150$ per annum for a 'housekeeper and ladies' maid'. Several other unnamed individuals paid between $£ 50$ and $£ 150$ per annum to accommodate governesses there. Non-relatives paid for the maintenance of several women committed to Stewarts. These included three servants, a governess, a laundress, a stitcher and a teacher, though these were at lower rates (approx. $£ 50$ per annum). For example, a Mrs. 
Jameson, Mrs. Moore and Dr. Leet paid $£ 50, £ 40$ and $£ 30$ respectively for the maintenance of a laundress, a servant and a governess. These individuals are among the few in the financial accounts whose relationship to the patient was not specified, implying these individuals were, in fact, employers, rather than relatives or friends. This highlights the high value placed on servants and employees in Irish households and suggests that even outside traditional family settings, friends or employers were willing to invest in voluntary asylum care for women.

While designated occupations were relatively less common amongst female paying patients from rural areas, farming was more common. The percentage connected to farming either directly, through marriage or by birth is shown in Table 4.12. Notably, none of the women admitted to Bloomfield or Highfield was in this category, while more than half of female admissions to Ennis (57.9\%) and Enniscorthy (63\%) were linked to farming. One major difference arises between the two rural samples. At Ennis, a large proportion of farming women were listed as relatives of farmers but at Enniscorthy over one-third were identified simply as 'farmer'. This mirrors national trends. In Leinster, middle-aged or elderly widows were often reluctant to pass their family farm to a son. In the West of Ireland, 'the transmission of farms between the generations appears to have been accomplished more smoothly' and women farmers were less common. ${ }^{80}$ Despite their engagement in most kinds of agricultural work, women were not described as farmers either in the census or by themselves unless they were the heads of households. ${ }^{81}$ This would appear to hold true for paying patients admitted to Enniscorthy. For example, Ellen $\mathrm{McC}$, who was admitted in 1898, aged fifty-three and single, lived with her 'married nephew, but house and place are hers. Has a big farm, over 100 acres. ${ }^{82}$ Maria C., a forty-year-old widow admitted in 1897, had overseen her twenty acres and her brother described her as a 'good business woman on farm'.

\section{Conclusions}

Elizabeth Malcolm has provided what she terms a 'superficial' profile of patients in Armagh, Belfast, Omagh and Sligo district asylums at the turn of the twentieth century. Her findings suggest that the typical Irish asylum patient was a male labourer, from a labouring or small farming family, Catholic and single. ${ }^{83}$ Adopting this methodology, between 1868 and 1900, the 'typical' paying patient committed to the district asylums 
was also a male farmer. He too was Catholic, unless he was committed to Belfast, and single. This remarkably similar profile reveals that paying patients admitted to district asylums differed little from the total populations of these asylums. In contrast, the 'typical' voluntary asylum patient was a Church of Ireland (or Quaker in Bloomfield) single woman with no former occupation. Given wide variations between the types of patient committed to the private asylums, it is necessary to provide separate 'superficial profiles' for each. The 'typical' admission to St John of God's was a single Catholic man in trade, that to Hampstead was a single Church of Ireland man with an 'other occupation', usually a white-collar profession, and that to Highfield a married Church of Ireland woman with no occupation.

These profiles reveal a great deal about the socio-economic background of the individuals and families who used these asylums. Unlike district asylums, Bloomfield and Stewarts admitted more women than men. Other asylums such as St Vincent's voluntary asylum (see Chap. 2 ) and Highfield private asylum had a policy of admitting only women. This complicates Oonagh Walsh's assumption that non-pauper women in Ireland were more often accommodated in the home. ${ }^{84}$ Although both MacKenzie and Walsh have argued that families were more willing to pay for male patients' asylum care because of their 'greater economic importance', 85 this study has revealed that in the Irish context, relatives and friends were willing to invest large sums of money in women's care and treatment. While this might suggest a greater determination to 'dump' unwanted female relatives, there is no concrete evidence to support this.

The occupational profile of patients in this study provides some clues as to the sort of people confined in different kinds of institutions. The underrepresentation of those in the most prominent trades of the period suggests that their families could not afford to pay for their care. Whitecollar professionals such as lawyers, doctors and accountants were most often found in voluntary and particularly private asylums. Men and women described as farmers were from a variety of social backgrounds, with significant inter- and intra-regional variation and could be anything from a smallholder to a relatively wealthy landowner. The religious profile of their cohort also points towards the Catholic middle classes emerging steadily in rural Ireland. However, members of the Church of Ireland were over-represented in voluntary asylums and in Hampstead and Highfield, demonstrating that the Catholic middle classes were seeking accommodation elsewhere. Voluntary and private patients' 
occupational profile corroborates this statement; the occupations listed tended to be dominated by Protestants in this era. While a large proportion of women in this study were described as having had no previous occupation, admissions register entries were concerned with demarcating the economic profile of these individuals and thus demonstrate a wide range of female occupations. A relatively small proportion of women in this study were assigned designated occupations. While work outside the home for women has tended to be aligned with financial necessity or even desperation, those engaged in non-domestic work in this study were usually connected to more 'respectable' forms of employment: shop girls, drapers, nurses and nuns. Sources such as these may thus add to our understanding of women and work in nineteenth-century Ireland.

\section{Notes}

1. Report into the State of Lunatic Asylums, Part II, p. 36.

2. As has been shown, the 1875 Act attempted to address this concern in guiding boards of governors in their negotiation of appropriate maintenance fees.

3. First Report of the Inspectors General on the General State of Prisons of Ireland (342), H.C. 1823, x, 291, p. 9; 57 Geo. III, c. 106; 'Editorial Article 2,' Irish Times, 12 June 1860.

4. Melling and Forsythe (2006, p. 163).

5. O. Walsh (2004, pp. 73-74).

6. $\operatorname{Malcolm}(1989$, p. 205).

7. Showalter (1986).

8. Busfield (1994, p. 268).

9. Showalter (1981, p. 164).

10. MacKenzie (1992, pp. 129, 135-136).

11. O. Walsh (2004, pp. 73-74).

12. Vaughan and Fitzpatrick $(1978$, p. 3$)$.

13. Finnane (1981, p. 130), Cox (2012, p. 135), O. Walsh (2004, p. 73).

14. MacKenzie (1992, pp. 129, 135-136), O. Walsh (2004, pp. 73-74).

15. O. Walsh (2004, pp. 73-74).

16. Digby (1985, p. 175).

17. Cox $(2012$, p. 140), Malcolm (1999, p. 180). For more on marriage patterns in nineteenth-century Ireland, see Guinnane (1997, pp. 193-240), Connell (1962).

18. MacKenzie (1992, p. 169), Melling and Forsythe (2006, p. 116).

19. Digby (1985, p. 176); see Showalter (1981, p. 325).

20. Patient Accounts, 1858-1900 (Stewarts, Patient Records). 
21. Cox has also found the existence of 'affective' familial bonds in her study of district asylum patients. See Cox (2012, pp. 108-109).

22. O. Walsh (2004, pp. 73-74), MacKenzie (1992, pp. 135-136).

23. Patient Accounts, 1858-1900 (Stewarts, Patient Records); Patient Accounts, 1896-1900 (Highfield Hospital Group, Hampstead and Highfield Records); Patient Accounts, 1812-1900 (FHL, Bloomfield Records).

24. Ibid.

25. Cox (2012, p. 150).

26. 'Census of Ireland 1901,' accessed 6 January 2012, http://www.census.nationalarchives.ie. Twenty-nine out of the 166 patients discharged from Ennis, Enniscorthy, Richmond, Stewarts, Bloomfield, Hampstead and Highfield between 1898 and 1900 were identified in the 1901 Census. This identification was not possible for St John of God's because restricted access to the records dictated that patients' surnames could not be included on the database. Belfast was also omitted because patients' addresses were too vague to allow for definitive linkage between asylum and census records.

27. Female Case Book, 1898-1899 (GM, Richmond District Lunatic Asylum, pp. 469-471).

28. This is contrary to the arguments put forward in Scull (1982).

29. L. Walsh (2004, p. 265).

30. Ibid.

31. Admissions and Receptions Registers, 1841-1900 (PRONI, Purdysburn Hospital, HOS/28/1/3); Admissions-Refusals, 1868-1900 (CCA, Our Lady's Hospital, OL3/1.3); Admissions Registers, 1868-1900 (WCC, St Senan's Hospital, Enniscorthy); Admissions Registers, 1870-1900 (GM, Richmond District Lunatic Asylum); Admissions Registers, 18581900 (Stewarts, Patient Records); Admissions Registers, 1812-1900 (FHL, Bloomfield Records); Admissions Registers, 1885-1900 (SJOGH, Patient Records); Admissions Registers, 1826-1900 (Highfield Hospital Group, Hampstead and Highfield Records).

32. MacKenzie (1992, p. 130).

33. Religious affiliation was recorded systematically in the admissions registers for the four district asylums studied. It was recorded for $100 \%$ of first admissions to Belfast and Enniscorthy, 88.1\% for Ennis and 97.4\% for Richmond. Religious persuasion was not recorded in the admissions registers for Bloomfield, Stewarts, St John of God's, Hampstead or Highfield. However, through nominal linkage with surviving case notes, religious persuasion has been identified for 38.8\% of Stewarts', $11.1 \%$ of Bloomfield's, 16.5\% of St John of Gods' and 26.9\% of Hampstead and Highfield's first admissions. 
34. The headings used are taken from the lunacy inspectors' annual reports in their categorisation of private asylum patients' former occupations. Preference was given to this classification system over contemporary census headings because, like this study, the lunacy inspectors were dealing exclusively with asylum populations and working with data drawn from admissions registers. The additional headings of 'clerk', 'labourer' and 'police' have been added to the lunacy inspector's model to highlight the prominence or otherwise of these occupations within certain asylum populations. 'Son of', 'pensioner' and 'social class specified' were also added to circumvent the difficulties in accurately classifying these groups.

35. This umbrella term includes merchants, grocers, shopkeepers, drapers, bakers, carpenters, butchers and commercial travellers. For more on nineteenth-century Irish industry, see Bielenberg (2009).

36. For more on industry in the North of Ireland and particularly Belfast, see Gribbon (1989, pp. 298-309).

37. Daly $(1984$, pp. 23-30).

38. Ibid., pp. 32, 40-41.

39. Guinnane (1997, p. 39).

40. Ibid., pp. 41-43.

41. Jones (1995, p. ix, 1).

42. Guinnane (1997, p. 41).

43. Cited in Bell and Watson (2009, p. 18).

44. See Guinnane (1997, pp. 44-47).

45. See MacDonagh (1977), Ó Gráda (1989, 1994), Comerford (1989); W.E. Vaughan (1994), Hoppen (1998). For an overview of the Irish Land Wars, see Clark (1979).

46. Clinical Record Volume No. 4 (WCC, St Senan's Hospital, Enniscorthy, pp. 373-374; 317-378, 118).

47. Clinical Record Volume No. 5 (WCC, St Senan's Hospital, Enniscorthy, p. 197).

48. Clinical Record Volume No. 4 (WCC, St Senan's Hospital, Enniscorthy, p. 239; 359); Clinical Record Volume No. 6 (WCC, St Senan's Hospital, Enniscorthy, p. 215).

49. Clinical Record Volume No. 4 (WCC, St Senan's Hospital, Enniscorthy, pp. 231, 14).

50. Clinical Record Volume No. 3 (WCC, St Senan's Hospital, Enniscorthy, p. 211).

51. Admissions Registers, 1858-1900 (Stewarts, Patient Records); Admissions Registers, 1812-1900 (FHL, Bloomfield Records); Admissions Registers, 1885-1900 (SJOGH, Patient Records); Admissions Registers, 1826-1900 (Highfield Hospital Group, Hampstead and Highfield Records). 
52. Daly (1984, pp. 124-126).

53. Seventh Report on the District, Criminal, and Private Lunatic Asylums in Ireland [1981], H.C. 1854-1855, xvi, 137, p. 22.

54. Landlords usually let their land to 'intermediate landlords, commonly called middlemen, who sublet their holdings to smaller tenants and cottiers', meaning that they were not technically 'occupied' by their livelihood. See Donnelly (1989, p. 332).

55. Female Case Book, 1857-1887 (GM, Richmond District Lunatic Asylum, pp. $453,108,12)$.

56. Male Case Book, 1890-1891 (GM, Richmond District Lunatic Asylum, pp. 1-2).

57. Ibid., pp. 754-756.

58. Male Case Book, 1891-1892 (GM, Richmond District Lunatic Asylum, p. 58 ).

59. This medical officer's identity is unknown because he did not sign his case notes.

60. Male Case Book, 1891-1892 (GM, Richmond District Lunatic Asylum, pp. 146-147).

61. Ibid., pp. 146-147.

62. Ibid., p. 147.

63. Male Case Book, 1893-1894 (G.M, Richmond District Lunatic Asylum, pp. 433-435).

64. For example, Male Case Book, 1894-1895 (G.M, Richmond District Lunatic Asylum, pp. 53-54); Male Case Book, 1894-1895 (G.M, Richmond District Lunatic Asylum, pp. 49-50).

65. Male Case Book,1892-1893 (G.M, Richmond District Lunatic Asylum, pp. 737-739).

66. Daly (1997, pp. 2-3).

67. Ibid., p. 3.

68. Melling (2004, p. 192).

69. L. Walsh (2004, p. 265).

70. Michael (2004, p. 103$)$.

71. Daly (1997, p. 32).

72. Ibid., p. 19. This has been attributed alternately to the economic boom experienced in rural Ireland which enabled women to 'opt out of paid employment in favour of unpaid domestic work within the family' and the collapse of domestic spinning during the post-Famine period. See Bourke (1993).

73. Daly (1997, p. 7).

74. Ibid., p. 8 .

75. Daly (1984, p. 41).

76. Daly (1997, p. 32). 
77. Rains (2010, pp. 152, 199-200).

78. Melling (2004, p. 192).

79. Ibid., p. 199.

80. Daly (1997, pp. 19-22). For more on farming families in the West of Ireland, see Fitzpatrick (1980).

81. Census of Ireland, 1861-1911, Occupational Tables.

82. Clinical Record Volume No. 6 (WCC, St Senan's Hospital, Enniscorthy, pp. 175-176).

83. Malcolm (1999, p. 182).

84. O. Walsh (2004, pp. 73-74).

85. MacKenzie (1992, pp. 129, 135-136), O. Walsh (2004, pp. 73-74).

\section{REFERENCES}

Bell, Jonathan and Watson, Mervyn. A History of Irish Farming 1750-1950. Dublin: Four Courts Press, 2009.

Bielenberg, Andy. Ireland and the Industrial Revolution: The Impact of the Industrial Revolution on Irish Industry, 1809-1822. London and New York: Routledge, 2009.

Bourke, Joanna. Husbandry to Housewifery: Women, Economic Change and Housework in Ireland, 1890-1914. Oxford: Clarendon Press, 1993.

Busfield, Joan. 'The Female Malady? Men, Women and Madness in NineteenthCentury Britain.' In Sociology 27, no. I (1994): 259-277.

Clark, Samuel. Social Origins of the Irish Land War. Princeton: Princeton University Press, 1979.

Comerford, R.V. 'Ireland 1850-70: Post-Famine and Mid-Victorian.' In A New History of Ireland V: Ireland Under the Union, I, 1801-70, edited by W.E. Vaughan, 371-385. Oxford: Oxford University Press, 1989.

Connell, K.H. 'Peasant Marriage in Ireland: Its Structure and Development since the Famine.' Economic History Review 14, no. 3 (1962): 502-523.

Cox, Catherine. Negotiating Insanity in the Southeast of Ireland 1830-1900. Manchester: Manchester University Press, 2012.

Daly, Mary E. Dublin, The Deposed Capital: A Social and Economic History, 1860-1914. Cork: Cork University Press, 1984.

Daly, Mary E. Women and Work in Ireland. Dundalk: Dundalgan Press, 1997.

Digby, Anne. Madness, Morality and Medicine: A Study of the York Retreat, 17961914. Cambridge: Cambridge University Press, 1985.

Donnelly, James S. 'Landlords and Tenants.' In A New History of Ireland V: Ireland Under the Union, I, 1801-1870, edited by W.E. Vaughan, 332-349. Oxford: Oxford University Press, 1989.

Finnane, Mark. Insanity and the Insane in Post-Famine Ireland. London: Croom Helm, 1981. 
Fitzpatrick, David. 'Irish Farming Families before the First World War.' Comparative Studies in History and Society 25 (1980): pp. 339-384.

Gribbon, H.D. 'Economic and Social History, 1850-1921.' In A New History of Ireland VI: Ireland Under Union, 1870-1921, edited by W.E. Vaughan, 260356. Oxford: Oxford University Press, 1989.

Guinnane, Timothy. The Vanishing Irish: Households, Migration, and the Rural Economy in Ireland, 1850-1914. Princeton: Princeton University Press, 1997.

Hoppen, K. Theodore. The Mid-Victorian Generation, 1846-1886. Oxford: Oxford University Press, 1998.

Jones, David Seth. Graziers, Land Reform, and Political Conflict in Ireland. Washington, DC: Catholic University of America Press, 1995.

MacDonagh, Oliver. Ireland: The Union and Its Aftermath. London: Allen and Unwin, 1977.

MacKenzie, Charlotte. Psychiatry for the Rich: A History of the Private Madhouse at Ticehurst in Sussex, 1792-1917. London: Routledge, 1992.

Malcolm, Elizabeth. Swift's Hospital: A History of St. Patrick's Hospital, Dublin, 1746-1989. Dublin: Gill and Macmillan, 1989.

Malcolm, Elizabeth. 'The House of Strident Shadows: The Asylum, the Family and Emigration in Post-Famine Rural Ireland.' In Medicine, Disease and the State in Ireland 1650-1940, edited by Elizabeth Malcolm and Greta Jones, 177-195. Cork: Cork University Press, 1999.

Melling, Joseph. 'Sex and Sensibility in Cultural History: The English Governess and the Lunatic Asylum, 1845-1914.' In Sex and Seclusion, Class and Custody: Perspectives on Gender and Class in the History of British Psychiatry, edited by Jonathan Andrews and Anne Digby, 177-221. Amsterdam and New York: Rodopi, 2004.

Melling, Joseph and Bill Forsythe. The Politics of Madness: The State, Insanity and Society in England, 1845-1914. London and New York: Routledge, 2006.

Michael, Pamela. 'Class, Gender and Insanity in Nineteenth-Century Wales.' In Sex and Seclusion, Class and Custody: Perspective in Gender and Class in the History of British and Irish Psychiatry edited by Jonathan Andrews and Anne Digby, 95-122. Amsterdam and New York: Rodopi, 2004.

Ó Gráda, Cormac. 'Poverty, Population, and Agriculture, 1801-1845.' In A New History of Ireland V: Ireland Under the Union, I, 1801-1870, edited by W.E. Vaughan, 108-136. Oxford: Oxford University Press, 1989.

Ó Gráda, Cormac. Ireland: A New Economic History, 1780-1939. Oxford: Oxford University Press, 1994.

Rains, Stephanie. Commodity, Culture and Social Class in Dublin 1850-1916. Dublin and Portland: Irish Academic Press, 2010.

Scull, Andrew. Museums of Madness: The Social Organisation of Insanity in Nineteenth-Century England. Harmondsworth: Penguin, 1982. 
Showalter, Elaine. 'Victorian Women and Insanity.' In Madhouses, Mad-Doctors and Madmen: The Social History of Psychiatry in the Victorian Era, edited by Andrew Scull, 157-181. Philadelphia: University of Pennsylvania Press, 1981. Showalter, Elaine. The Female Malady: Women Madness and Culture in England, 1830-1980. New York, Pantheon Book, 1986.

Vaughan, W.E. Landlords and Tenants in Mid-Victorian Ireland. New York: Oxford University Press, 1994.

Vaughan, W.E. and A.J. Fitzpatrick (eds.). Irish Historical Statistics, Population, 1821-1971. Dublin: Royal Irish Academy, 1978.

Walsh, Lorraine. 'A Class Apart? Admissions to the Dundee Royal Lunatic Asylum, 1890-1910.' In Sex and Seclusion, Class and Custody: Perspectives on Gender and Class in the History of British and Irish Psychiatry, edited by Jonathan Andrews and Anne Digby, 249-269. Amsterdam and New York: Rodopi, 2004.

Walsh, Oonagh. 'Gender and Insanity in Nineteenth-Century Ireland.' In Sex and Seclusion, Class and Custody: Perspectives on Gender and Class in the History of British Psychiatry, edited by Jonathan Andrews and Anne Digby, 69-93. Amsterdam and New York: Rodopi, 2004.

Open Access This chapter is licensed under the terms of the Creative Commons Attribution 4.0 International License (http://creativecommons.org/licenses/ by $/ 4.0 /$ ), which permits use, sharing, adaptation, distribution and reproduction in any medium or format, as long as you give appropriate credit to the original author(s) and the source, provide a link to the Creative Commons license and indicate if changes were made.

The images or other third party material in this chapter are included in the chapter's Creative Commons license, unless indicated otherwise in a credit line to the material. If material is not included in the chapter's Creative Commons license and your intended use is not permitted by statutory regulation or exceeds the permitted use, you will need to obtain permission directly from the copyright holder.

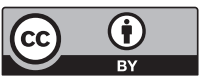

